\title{
Álbum de familia: escritura del trauma y memoria fotográfica en narraciones argentinas recientes
}

Las fotografías han ocupado un lugar central en los reclamos de verdad y justicia de los familiares de víctimas del terrorismo de Estado en Argentina y en su lucha por mantener viva la memoria. Este artículo analiza el uso de la fotografía en tres relatos "auto/biográficos" recientes: Diario de una Princesa Montonera -110\% Verdad- de Mariana Eva Pérez (2012); ¿Quién te creés que sos? de Ángela Urondo Raboy (2012) y Aparecida de Marta Dillon (2015). En los tres casos, la fotografía se erige como objeto "mágico", al que se aferra la memoria para reconstruir, a partir de ese instante congelado, toda una historia de vida familiar. Las fotos circulan de texto en texto y forman una especie de "álbum de familia" en el que las imágenes vienen a reponer la presencia de quienes ya no pueden dar cuenta de ellas en primera persona. Leer los usos que cada texto hace de los registros fotográficos puede ser una manera de comprender proyectos de escritura singulares que apuntan a recomponer una memoria que transita entre lo privado y lo público, entre los lazos rotos de la afectividad doméstica y familiar, y aquellos otros que se tienden en las luchas colectivas por la memoria.

Hace casi dos décadas Leonor Arfuch partía del análisis de una obra del artista francés Christian Boltansky, Álbum de la familia D., expuesta por entonces en el Museo Nacional de Bellas Artes de Buenos Aires y desembocaba en una reflexión sobre lo que significa la fotografía en el contexto argentino de la desaparición. Su trabajo planteaba un giro en la manera de concebir las imágenes en esta situación particular donde persiste un "reclamo no acallado" y las colocaba en el vértice de una interrogación: "¿qué desean esas imágenes, dispersas y recurrentes de nuestro álbum de familia colectivo? ¿qué nos piden?" ("Álbum" 11). La propuesta de Arfuch resulta curiosa y sugerente pues instala el poder de las imágenes "no en la atracción de lo que ofrecen sino en lo que piden, en lo que les falta" (11; énfasis en el original). De ese modo, las fotografías de los desaparecidos vendrían a instaurar un diálogo incesante con el presente, y toda la sociedad resultaría así interrogada a cada momento desde aquella orilla brumosa del pasado.

Las fotografías, en sus diferentes ocurrencias y formatos, entre ellas, las tomadas del ámbito privado del álbum familiar, han ocupado un lugar 
central en los reclamos de verdad y justicia de los familiares y en su lucha por mantener viva la memoria de esas víctimas atípicas que son los desaparecidos: sus fotos - señala Arfuch - atestiguan "la huella de un ser que no solo es pasado y otredad, no solamente un 'haber sido', sino todavía una insistencia en el llegar a ser" ("Álbum" 11). ${ }^{2}$ Podemos pensar en la utilización de las fotos ampliadas exhibidas en pancartas en las manifestaciones de organismos de derechos humanos como lo hicieron en sus rondas semanales Abuelas y Madres de Plaza de Mayo, o en los recordatorios que se publicaban (y aún se publican) en periódicos como Página 12, para mantener vivo el recuerdo y el reclamo de justicia - "esa pequeña solicitada en el diario que reemplaza el epitafio para los desaparecidos" (Dillon 95) -,o finalmente, fotos de restos óseos, de piezas dentales, de prótesis, recuperados en los expedientes judiciales de las causas que investigan el destino final de aquellos que no están. ${ }^{3}$

En el marco de las prácticas visuales, la fotografía ha sido un soporte central en las obras en las que se intenta reconstruir la memoria del trauma por parte de los familiares de las víctimas. Natalia Durán reúne un conjunto de ensayos fotográficos que trabajan sobre imágenes de desaparecidos en narraciones (auto)biográficas e identitarias, y analiza los modos de construcción visual de la memoria. Incluye las obras Arqueología de la ausencia de Lucila Quieto, Ausencias (2007) de Gustavo Germano, Buena memoria (1997) de Marcelo Brodsky y Fotos tuyas (2006) de Inés Ulanovsky. Las fotos con las que los autores trabajan no son imágenes públicas, reapropiadas en el seno familiar, sino imágenes que salen de un cajón o de un álbum atesorado y que, intervenidas y articuladas, constituyen un potente relato sobre los efectos de las ausencias en la intimidad (167). Durán se refiere a la aparición de nuevos discursos, especialmente visuales, desarrollados por la generación de los hijos, quienes exploran y producen modos innovadores de abordar su memoria e identidad, los cuales no siguen un recorrido lineal y unívoco e incluyen, a menudo, una tematización metarreflexiva sobre la propia memoria. Además de los ensayos fotográficos, la autora propone incorporar a esta "constelación" de obras visuales, las películas Los rubios de Albertina Carri (2005) y $M$ de Nicolás Prividera (2007), como así también la serie de dibujos y pinturas Los niños del proceso de María Giuffra, entre otros (167).

Pareciera que esa interrogación a la que alude Arfuch ha interpelado asimismo con fuerza a los jóvenes escritores de la nueva generación, hijos de militantes y desparecidos muchos de ellos, que intentan responder con sus relatos a las preguntas que las fotografías les han planteado. Toda una gama de funciones narrativas y representaciones de la fotografía, que llegan a su inclusión y reproducción en el cuerpo textual, aparecen en las 
obras que me propongo analizar. Pero en primer lugar, esas imágenes son disparadores del recuerdo y la memoria - imposibles de recuperar muchas veces - esto es, del relato que pone como punto de partida el retrato de los protagonistas. En testimonios, autoficciones, biografías y diversas narrativas ficcionales de esta generación de posdictadura, hay una constante referencia a la fotografía como soporte de la memoria al momento de reconstruir una narración de vida en la que se pone en juego la propia identidad fracturada por una ausencia parental o aún, expropiada al ser borrados los orígenes filiatorios verdaderos, como es el caso de los niños que fueron mantenidos en cautiverio por sus apropiadores.

Lo que me interesa analizar en este trabajo es el uso de la fotografía en lo que voy a denominar como relatos "auto/biográficos" de las hijas de víctimas del terrorismo de Estado, tanto en su versión reproducida, e incorporada en una especie de montaje en el cuerpo del texto, como en la forma mediatizada, a través de una descripción de su contenido, pero en todo los casos como objeto "mágico", al que se aferra la memoria para reconstruir, a partir de ese instante congelado, toda una historia de vida familiar. ${ }^{4}$ Las fotos circulan de texto en texto, y forman una especie de "álbum de familia" en el que los lazos de sangre son reemplazados por la condición que los une: esa falta que vienen a reponer, como una prótesis siempre insuficiente, las imágenes nítidas o borrosas de quienes ya no pueden dar cuenta de ellas en primera persona. La idea de álbum fotográfico en el contexto de la violencia estatal que invadió el ámbito de lo privado, evoca lo trágico, "una fractura irreparable de las genealogías que no se salda con el paso del tiempo y las generaciones" (Arfuch, "Álbum" 11).

En los últimos años, se han publicado en Argentina numerosas obras escritas por autore/as pertenecientes a la generación de los hijos de quienes participaron de los movimientos revolucionarios y, luego, fueron víctimas del terrorismo de Estado en los años 70; en muchas de ellas, la escritura vuelve sobre la experiencia traumática de la desaparición de los progenitores y del ocultamiento de la verdad y adopta una serie de matices que la diferencian de aquella producida por las víctimas sobrevivientes o por autores que fueron testigos contemporáneos de estas situaciones traumáticas. ${ }^{5}$ De esta constelación de obras, que se instalan en un espacio discursivo que va de la ficción a los registros más testimoniales, voy a abordar tres que fueron publicadas en los últimos años y con las cuales es posible armar un corpus por el aire de familia que presentan: Diario de una Princesa Montonera -110\% Verdad- de Mariana Eva Pérez (2012); ¿Quién te creés que sos? de Ángela Urondo Raboy (2012) y Aparecida de Marta Dillon $(2015)^{6}$

Antes de avanzar, y para disponer de una mirada más amplia y en al- 
gún modo diacrónica, es interesante recordar el corpus de narrativas testimoniales de sobrevivientes y familiares escritos entre 1984 y 2006 que Rossana Nofal reúne y analiza. Para poder evaluar lo novedoso y heterogéneo de las nuevas voces y perspectivas que aparecen hacia el final del período considerado, Nofal lee esos testimonios en términos de guerra y postula una transformación en los sujetos cuyas vidas allí se cuentan sucesivamente como desaparecidos, militantes y soldados. ${ }^{7}$ Esta lectura le permite descubrir matices diferenciales entre los primeros testimonios y aquellos escritos en los albores del siglo XXI. Si los primeros, publicados entre 1983 y mediados de los años noventa, "se inician con la pregunta sobre la identidad de las víctimas de la represión como sujetos desaparecidos" (240; énfasis en el original), en los posteriores, se destaca la aparición en la superficie de memorias subterráneas referidas a las acciones armadas en términos de guerra, los desaparecidos se convierten en soldados y "la narración explicita un cuadro más complejo que el de la representación de las víctimas absolutas" (240); ahora se otorga voz a los cuadros subalternos con objeto de desentrañar la opción por las armas considerada válida en aquel momento histórico y la crítica apunta a una dirigencia "irresponsable" y militarizada. Los testimonios juegan con la tensión entre memoria e historia, y reivindican el espacio literario de la ficción como lugar en el que la imaginación puede volver a la infancia para explicar los motivos y razones de un presente combativo (250).

Ahora bien, en los relatos "auto/biográficos" que he seleccionado, se desplaza el acento de la estructura político-partidaria o de la organización armada de naturaleza militar, hacia el ámbito familiar y hacia figuras cuyas actuaciones como militantes y soldados no desaparecen, pero en quienes se anteponen los roles de madres y padres, en el ámbito domésticofamiliar, de quienes sostienen la narración, como piezas ineludibles en un armado identitario, complejo, inestable, inconcluso, conflictivo, y que vienen a ser la clave a partir de la cual se desarrolla la escritura del yo. ${ }^{8} \mathrm{Ya}$ no son compañeros de militancia e integrantes de agrupaciones armadas quienes hablan como en el caso de Miguel Bonasso o de Alicia Partnoy. En los textos aquí reunidos, quienes vienen a tomar la palabra son los hijos, en muchos casos también víctimas directas de secuestros, torturas, cautiverios, robos de identidad, para recomponer una novela familiar que quedó incompleta. Son aquellos que en los 90 iniciaron su participación en los movimientos de Derechos Humanos a través de la agrupación H.I.J.O.S., y se sumaron así a los reclamos de verdad y justicia que desde los primeros años de la dictadura llevaban adelante Madres y Abuelas de Plaza de Mayo.

Es importante hacer otra aclaración previa referida a la forma gené- 
rica que adoptan estos relatos. Los llamo "auto/biográficos" pues todos ellos participan de una doble naturaleza en relación con esos géneros canónicos: por un lado, es evidente la necesidad de generar una "narrativa vivencial" en la cual la escritura sea soporte de una identidad, la de la autora-narradora-protagonista, que se va configurando en la trama textual, en una narración que buscar restablecer los lazos filiales destruidos por la violencia del terrorismo de Estado. Por el otro, son también biografías ya que para esa construcción es preciso reponer la historia de los progenitores, desde su infancia y adolescencia hasta el momento de su asesinato o desaparición. En este sentido podríamos incorporar estos tres textos en lo que Leonor Arfuch ha denominado el "espacio biográfico" (Espacio), que incluye las diferentes maneras en que las vidas "reales" se narran en diversos formatos retóricos y soportes tecnológicos, que van de la autobiografía clásica a la entrevista periodística o del diario íntimo al weblog en Internet. Esta útil conceptualización surge

del intento por superar los límites - las fronteras - de los géneros auto/biográficos canónicos para abarcar la multiplicidad de formas y géneros - mediáticos, audiovisuales, cinematográficos, teatrales - en los cuales se despliega actualmente la narrativa vivencial, con una gran diversidad retórica respecto de sus ancestros del siglo XVIII y una aparición que desafía cada vez más el umbral, nunca nítido, entre público y privado. (Arfuch, “Cronotopías” 249; énfasis en el original)

Veremos que dos de estos textos fueron inicialmente blogs que tuvieron sus autoras como modo de ir dejando registro de un proceso ligado estrechamente al develamiento de ciertos hechos decisivos relacionados con sus orígenes y sus primeros años de vida.

Héctor Vezzetti, en una clasificación que resulta ordenadora de la inmensa proliferación de abordajes teóricos sobre políticas de la memoria del terrorismo de Estado, distingue cinco tipos: 1) la memoria de los crímenes y de los criminales, necesaria para establecer la verdad "jurídica" de los hechos y juzgar a los responsables, y que se sirve de los testimonios de los sobrevivientes; 2) la memoria familiar, de vínculos afectados por esa ofensa moral; una memoria asociada a los procesos de duelo, y a la búsqueda de los niños apropiados; 3) las memorias de grupos que reafirman identidades y afiliaciones del pasado, desde el lugar del militante revolucionario, pero también desde el relato de la "guerra antisubversiva"; 4) la memoria intelectual ligada a saberes e investigaciones históricas; y por último, 5) la memoria pública, política, a cargo del Estado, que discute ese pasado desde tradiciones, valores y afiliaciones específicas y combina o traduce todas las demás (4). 
En el caso de las obras mencionadas, es principalmente el segundo tipo, la memoria familiar de los/as hijos/as, el que se encuentra movilizado y opera como motor del relato. Pero desde allí, el relato se desplaza invariablemente hacia la primera y la última categoría, por cuanto esa memoria familiar, y la posibilidad de recuperarla, depende en gran medida de instancias y decisiones institucionales que sobrepasan la esfera de lo privado, y tienen como protagonistas a la Justicia y al Estado. Si es casi un lugar común afirmar que el trabajo de la memoria es del orden de la invención, aún en sus formas autobiográfica y/o testimonial, en estos textos, la invención se torna literal por cuanto los narradores, bebés o niños al momento en que sus progenitores fueron secuestrados, desaparecidos y/o asesinados, deben imaginar un pasado que heredaron, muchas veces sin haberlo vivido y, en otras, apenas entrevisto en borrosos recuerdos de infancia, recuperados en fotos de familia: son estas imágenes, a las que se alude en no pocas de estas obras, las que permiten recomponer rostros, armar situaciones, tomar posición y "manejar" un legado cargado de heroísmo y de leyenda. ${ }^{9}$ En este sentido, las intervenciones estéticas de los hijos e hijas de los desaparecidos, en sus diferentes expresiones artísticas - películas, testimonios, relatos, pintura, obras de teatro - serían "ficciones críticas de la memoria" como las denominó Ana Amado, por cuanto construyen una perspectiva generacional intransferible como la de sus propios padres y se atreven a interpelar una cultura histórica y no simplemente heredarla.

Lo que me interesa indagar en este trabajo es el modo en que estos textos reinventan el pasado desde una perspectiva particular y escriben el trauma de los orígenes y la identidad a partir de la imagen fotográfica. ${ }^{10} \mathrm{De}$ esta manera, y por medio de diferentes modos de representación de las imágenes, sería posible hacer una lectura de estos relatos y relevar diferencias en los modos de construir la memoria en cada una de estas tres autoras.

LA MEMORIA INTERVENIDA: DIARIO DE UNA PRINCESA MONTONERA $110 \%$ VERDAD- DE MARIANA EVA PÉREZ

"Estas arrugas en el entrecejo, estas ojeras, antes no estaban. Pero bueno, yo estoy viva, envejezco, no soy la foto de mi mamá"

(Pérez 114)

Mariana Eva Pérez es hija de militantes montoneros y nació en 1977. Cuando tenía quince meses, el 6 de octubre de 1978, la secuestraron junto a 
su madre, Paty, quien estaba embarazada. Horas más tarde la dejaron con la familia paterna. A su padre José lo secuestraron en Martínez, el mismo día y el mismo grupo de tareas. Ambos aún permanecen desaparecidos. Pérez forma parte de la agrupación H.I.J.O.S. en la que milita desde la adolescencia.

Ya desde el título, se instaura un registro paródico y humorístico que va a atravesar todo el testimonio: las famosas Memorias de una princesa rusa, versión femenina del Marqués de Sade, pieza clásica de la literatura erótica y fuente de fantasías sexuales para muchas generaciones de hombres, deviene en este diario de una Princesa Montonera, que promete un plus de verdad, más acentuado que cualquier otro testimonio." Ese agregado pone en alerta y condiciona por su propio absurdo el pacto de veracidad que podríamos establecer como lectores de una obra autobiográfica: "Ustedes saben que mi diario es mayormente ficción..." (133), dice en algún momento la narradora quien escamotea, a lo largo de todo el diario, bajo el nombre de Princesa Montonera, su verdadero nombre, como así también los apellidos de sus padres.

La obra de Pérez fue originalmente un blog que tuvo la autora y mantiene, en su versión édita, el formato de ese tipo discursivo virtual: fragmentos que van relatando distintos momentos en la vida de la narradora protagonista y que conforman una especie de mosaico autobiográfico de esta hija de desaparecidos. ${ }^{12}$ Las entradas del diario llevan títulos, pero no se consignan fechas, lo cual contribuye a una cierta superposición de planos temporales que desbarata la sucesión cronológica propia del género. Distintas alternativas de la vida cotidiana de la autora en el tiempo de escritura del blog se mezclan con sueños, correos electrónicos, fotografías, letras de tango, avisos de alquiler. A partir de esos fragmentos se puede reconstruir un recorrido vivencial que va desde la adolescencia de la hija y tiene como objetivo conocer su propia historia, encontrar a su hermano nacido en cautiverio y luego apropiado, y la historia de sus padres, las cuales se van armando a partir de un entramado caótico en el que se mezclan nombres, lugares, épocas, fotografías, sueños. Así, será central su paso por una agrupación de derechos humanos, el reencuentro con su hermano y con amigos y compañeros de militancia de sus padres; la participación en diversos eventos y homenajes; su asistencia a los juicios a los responsables por el secuestro y desaparición de sus progenitores en la ESMA...

Lo que llama la atención como rasgo disruptivo de la obra es el tono lúdico e irónico que atraviesa toda la narración. Esto se inicia con la forma desprejuiciada e irreverente de hablar de la militancia de los propios hijos de desaparecidos y produce una ruptura con otras formas de puesta en 
discurso testimonial de la experiencia traumática del terrorismo de Estado, que mantienen un tono serio y trágico a la vez. Pérez se nombra a sí misma como una "militonta", los "hijos" son "hijis", el proyecto de la agrupación de reconstruir biografías de los desaparecidos es "el temita" o el "Proyecto Re Importante"; pareciera que todo lo que se aborda en el blog resulta banalizado con la incorporación de enunciados de la cultura de masas, del discurso publicitario, de las nuevas tecnologías de comunicación:

Mandá TEMITA al 2020 y participá del fabuloso sorteo. "Una semana con la Princesa Montonera”. Ganá y acompañala durante siete días en el programa que cambió el verano: ¡El Show del temita! ... El Temita: audiencias orales, homenajes, muestras de sangre, proyectos de ley, atención a familiares de la tercera edad y militontismo en general. (39)

Lo trágico de la experiencia se transfigura en una aparente levedad que quita dramatismo a lo narrado. Sin embargo, se trata de un recurso novedoso en las formas de escritura del trauma que no impide la inscripción de la memoria en el registro escrito y, al mismo tiempo, instala una distancia crítica hacia distintos tipos de organización autoritaria de esa militancia, tanto de los padres como de los hijos, y hacia ciertas figuras en especial. En un momento la protagonista, cuyo nombre nunca se menciona, es expulsada de la agrupación en la que milita y que no sabemos cuál es pues en su lugar aparecen tres asteriscos: "Empecé a trabajar en ***. Estaba tan embalada que hasta dejé la facultad un cuatrimestre" $(40){ }^{13}$ La recuperación de su hermano, nacido en un centro de detención y apropiado por un matrimonio, no impide que la relación entre ellos sea altamente conflictiva y que el supuesto amor fraterno se trasmute en una pelea que incluye reiterados reproches y lucha por bienes materiales. Los vínculos familiares no se restablecen de manera armónica a partir del conocimiento de la verdad. Pérez propone una mirada crítica y desmitificadora sobre tópicos centrales que atañen a esta generación de hijos: la militancia, el autoritarismo, la falta de humor, la vida "familiar" después de recuperar a hijos y hermanos apropiados, etc. A pesar de esto, no hay un reproche hacia la opción de los padres por la militancia y su compromiso político, sino una crítica al tipo de organización armada que los cobijó. ${ }^{14}$

Aparecen ocho fotografías a lo largo del Diario; me voy a detener en aquellas en que aparecen el padre o la madre. "Mi primera foto con mi papá" es la leyenda escrita sobre una imagen en blanco y negro en la que se ve el rostro de la autora ya adulta junto a una fotografía ampliada de su 
padre, foto característica de las que se emplearon en las marchas de las Madres y Abuelas y en los eventos para reclamar verdad y justicia. En realidad, aquí la ironía está dada en que esa imagen no recupera una escena de la vida real, en la que se habrían encontrado padre e hija, sino que hay una "composición" ficticia en la que el rostro ampliado del padre en una fotografía se superpone al de la hija como única manera de recobrar esa foto faltante en el álbum familiar. Más adelante, y en un apartado que lleva por título "Espiritismo", se refiere a la imagen de su madre que aparece en sueños y se reproduce el rostro de una muchachasupuestamente la madre, Paty - en lo que sería una foto carnet. Sin embargo, en las "referencias fotográficas" que aparecen al final, se aclara que la mujer en la foto es Ana María Lanzilloto (211) y no su madre. La tercera foto es del padre joven cuando integraba una banda de rock, sobre la cual se ha escrito en grandes letras "Papi es un rockstar"; la cuarta es un fotomontaje en el que aparecen madre e hija rodeadas de personajes siniestros, enmascarados, que intentan separarlas; y la quinta, estaría tomada en una marcha, con una leyenda que señala a dos mujeres riendo y dice "El trencito de la alegría" en un costado, y en el otro, una flecha señala a la autora y dice "Princesita Montonera en su torre solitaria", y más abajo, en dirección a la fotografía de su madre que lleva en las manos, otra leyenda: "Paty, siempre perfecta". Las fotos y sobre todo, su falta, recobran un valor mítico; son una pieza clave en la reconstrucción de los lazos filiales que han sido cortados; pero a su vez hay intervenciones en todas ellas como una forma de manipular aquello que no quedó registrado o que, habiendo sido registrado, no responde a lo que se desea guardar en el archivo. Al probarse un vestido que habría sido de su madre, para asistir a una boda, la Princesa Montonera hace una especie de declaración de principios que podría servir como clave para entender su particular política de la memoria:

El regalo de Site [el vestido que fue de su madre] me pesa. Hasta que pienso que soy vintage, soy la niña-vieja criada por los abuelos, la que teje crochet, la que dice: entre pitos y flautas se hicieron las doce, y no es un chiste, la custodia de fotos, cartas, libros, platos, copas, tantas cosas, demasiadas, pero mías. Y esto es lo que hago con todo eso: tomar lo que me gusta, transformarlo, hacer de eso heredado algo propio. (165)

En esta confesión se condensa el proyecto autobiográfico y narrativo de la autora, su propia forma de escribir el trauma: ¿Cómo se hace de lo heredado algo propio? Ese pareciera ser el desafío al que se enfrenta Mariana Pérez al escribir su Diario. Pues bien, el caso de la cuarta fotogra- 
fía descrita más arriba podría ser un ejemplo de esas transformaciones a las que la autora somete ese material heredado y lo incorpora a su diario. La descripción de la foto en un apartado denominado "Trouvé" dice lo siguiente:

... Martín sostiene en brazos a un bebé. Paty estira el cuello hacia atrás y hacia un lado para verle la cara. Ella está en el centro de la foto, Martín está cortado. Esa foto me perturba. Porque en esta perspectiva desde abajo, veo mi cuello, mi sonrisa y mi nariz en Paty. Y por ese bebé que no soy yo, que no es ningún hijo nacido de Paty y Martín, pero podría ser. (169)

Paty es la madre de la Princesa y Martín, un ex-novio que vive actualmente en Francia, donde pasó a vivir su exilio. El fotomontaje deja intacta la figura de la madre pero reemplaza a Martín por una figura enmascarada que no es otro que el villano más importante de la saga Star Wars, Darth Vader, y al bebé por una foto de la autora en su niñez; entre madre e hija, aparece una mano de grandes proporciones, supuestamente de aquel personaje que intenta separarlas. La intervención se completa con el rostro dibujado de otro enmascarado sobre el fondo superior derecho. Todo esto transforma una foto "inocente", cuya descripción muestra a una pareja con un bebé, en una imagen siniestra, en la que lo familiar y lo extraño se funden para transmitir la inquietante extrañeza que provoca su visión en la autora. ${ }^{15}$ De este modo, palabras e imágenes se articulan, a partir de una intervención sobre aquello que es recibido como legado para recomponer una memoria fracturada y plena de huecos. Sin embargo, esos huecos no se completan simplemente con la incorporación de la fotografía al álbum familiar, sino que quien arma ahora ese álbum, puede intervenir y "retocar" esa memoria fotográfica, y apropiársela de acuerdo con sus propios sentimientos.

LA MEMORIA MUTILAdA: ¿QUIÉN TE CREÉS QUE SOS? DE ÁNGELA URONDO RABOY

"A mi álbum le faltan un par de figuritas" (Urondo Raboy 196)

Ángela es hija del poeta y militante montonero Francisco "Paco" Urondo y de la periodista Alicia Cora Raboy, quien militaba en la misma organización. El padre es asesinado en una emboscada callejera en la ciudad de Mendoza, la madre secuestrada y desaparecida en esa misma ocasión y la hija, de once meses de edad, también secuestrada, llevada a la 
Casa Cuna de esa ciudad y luego entregada por la justicia a los familiares maternos.

La "auto/biografía" está estructurada en tres partes. La primera, "Documentos (palabras inapelables)", incluye, entre otros, un testamento manuscrito del propio Urondo, una carta de Alicia Raboy a su madre y hermanos, dos fotografías, notas periodísticas, transcripciones de actas policiales labradas con motivo del supuesto "enfrentamiento armado" en el que murió Urondo, las versiones de Rodolfo Walsh y de Horacio Verbistky sobre el asesinato de su compañero, copia de artículos periodísticos, transcripciones de los testimonios brindados en el juicio que se desarrolló, treinta y cuatro años después, contra los acusados por el asesinato del escritor y el secuestro y desaparición de su pareja Alicia. La segunda parte, "Crónicas (palabras para afuera)", comprende la narración en primera persona de la autora, acerca de cómo descubre su verdadera identidad, el conflicto con la familia materna que la crió pero, al mismo tiempo, le cambió el apellido paterno por el de su madre y le ocultó durante casi veinte años toda la verdad acerca la muerte de su padre y desaparición de su madre, y el proceso que la llevó a solicitar un trámite de "desadopción" para recuperar su verdadero nombre y filiación..$^{16}$ Asimismo, esta crónica incluye el relato de su acercamiento y toma de distancia con la agrupación H.I.J.O.S. a mediados de los 90 por diferencias en la manera de aludir a la militancia de sus padres. Esta segunda parte aparece compuesta de fragmentos breves que no siguen un orden cronológico definido: van del tiempo presente de la escritura a la evocación de la historia familiar de la madre. ${ }^{19}$ Por último, la tercera parte, "Conclusiones (palabras interiores)", se aleja del formato "crónica" y resulta la más "literaria", casi introspectiva e incluye poesías, poesías en prosa, narraciones de sueños, reflexiones, misceláneas. Se agrega una muy breve cuarta parte, "Correspondencia (palabras nuestras)", una carta de Ángela dirigida a sus padres, Francisco y Alicia.

En las primeras páginas se incluyen dos fotografías de la autora bebé junto con su madre en una de ellas, y con su padre en la otra. En esta última vemos solamente el bigote, la boca y el mentón del rostro de Urondo, quien está sentado y tiene sobre su falda a una Alicia de unos pocos meses. Como dice la autora, no existe ninguna fotografía de ellos tres juntos, "este es nuestro mejor retrato familiar" (16). En el apartado siguiente, que lleva por título "Fotografías", la autora cuenta que tiene cuatro fotos con su madre, una a colores y las restantes en blanco y negro; $\mathrm{y}$ aporta datos sobre las fotos en las que está junto a su padre y que ha recuperado recién a los 35 años. En ese momento, Urondo había pasado a la clandestinidad y no dejaba que lo fotografiaran: "Mi hermano, 
desobedeciendo la norma, tomó esas dos fotos que son las únicas en las que estamos papá y yo juntos ... En ambas papá sale a media cara" (18).

¿Cómo funcionan las fotografías en este relato y qué señal puede darnos su utilización acerca de la manera en que la autora aborda la memoria por vía de la escritura? El álbum familiar aparece al comienzo ocupando un espacio en blanco que ha sido definido por el silencio que durante años la familia que adoptó a Ángela mantuvo, en particular, sobre la figura del padre: "Papá, en cambio, era un verdadero secreto, mayúsculo, sin medias tintas y con todas las letras, tan secreto que no existía un solo dato de él" (140). Aún las fotografías en las que la hija aparece con su padre, y que se recuperan como un tesoro, están incompletas: el rostro del padre está cortado, no se ven sus ojos. La clandestinidad del padre se materializa en esa falta, en ese rostro que no se puede identificar.

En una poesía incluida en la tercera parte de la obra, titulada "Incompleto", Ángela utiliza dos sentidos corrientes de la palabra "álbum" para reflexionar sobre los comienzos que no se pueden reconstruir porque han sido "robados", y en este caso, el inicio de su propia vida. El álbum de fotografías es reemplazado por el álbum de figuritas que los niños coleccionan e intercambian entre ellos para completar - ese es el desafío y la promesa de un premio - cada uno de los espacios vacíos:

A mi álbum / le faltan un par de figuritas. / Pensé que las tenía todas, pero no / faltan unas viejas, del principio. / Me había dado cuenta de nada, hasta que un día, / al fondo de una cartera vieja, apareció / este bollito todo aplastado y amarillo / que era de mi álbum. Yo lo reconocí enseguida / Lo habían arrancado de cuajo con tanta prolijidad / que nunca pude notar su ausencia (196)

Esta estrofa intermedia sirve para operar el salto de uno a otro sentido de la palabra "álbum", del fetiche infantil, al registro en imágenes de la vida familiar y, de allí, al propio relato de los orígenes sobre el que se puede erigir una subjetividad: "Convencida de que todas las historias / tenían principio abierto, me pareció normal empezar / sin prólogo y por la décima hoja. Y las / primeras páginas, llenas de espacios vacíos" (196).

Si el relato autobiográfico, y la propia identidad, requieren construirse a partir de un origen certero, en este caso son arenas movedizas sobre las que se intenta marcar el punto inicial de una vida. Una historia "con principio abierto" desafía la posibilidad de narrar la propia experiencia y erigir la identidad, puesto que hay versiones diferentes y enfrentadas de esos orígenes: una versión oficial y otra que se conoce mucho después y viene a cuestionar la veracidad de ese relato. Sin embargo, la escritura se propone completar esos espacios vacíos de las primeras páginas del 
"álbum" con figuritas que resultan "inapelables": son los documentos de la primera parte. El primero de ellos es la palabra escrita del padre en un "casi testamento" en el que reconoce a su hija nacida de la relación extramatrimonial con Alicia Raboy y testifica a favor de sus tres hijos a quienes declara herederos de los bienes que posee (derechos de autor de obras literarias, guiones de TV y de cine); y luego las fotografías: las dos imágenes que se reproducen y el apartado en el que se inventarían las fotos existentes y se comentan las fotos reproducidas. ${ }^{18}$ Son estos documentos inapelables los que sirven de origen a la narración posterior, son aquellos pilares sobre los que se puede desplegar una escritura del trauma; si bien deficientes en su naturaleza (el cuasi testamento y las fotos con el rostro cercenado del padre) y en su número, son las piedras fundacionales disponibles sobre las cuales erigir una historia de vida y armar una nueva configuración familiar.

A partir de ese inicio, Ángela intenta reconstruir su verdadera identidad, recuperada cuando ya era adulta y en ese tránsito va a ajustar cuentas con diversos actores involucrados en el destino de sus padres y en el suyo propio, a saber, con la "Orga", esto es, con la estructura jerárquica de Montoneros que lleva a Juicio Moral Revolucionario a sus padres por haberse enamorado y por tener gustos burgueses, y haberlos desterrado a Mendoza totalmente desprotegidos. Asimismo critica a la agrupación H.I.J.O.S. a la que se incorpora a mediados de los 90, cuando se entera de que es hija de desaparecidos, por haberla expulsado al cuestionar una proclama programática en la que la regional Capital Federal se proponía reivindicar la lucha armada de la generación de sus padres; y reprocha y denuncia a la familia materna, que la dio en adopción a una prima de la madre y a su marido, que la separó de su medio hermano, Javier, y de su tía Beatriz, le borró el apellido Urondo, y le ocultó la verdad durante 19 años, al decirle que sus padres habían muerto en un accidente de auto. ${ }^{19}$

A diferencia de lo que ocurre en el Diario de Mariana Pérez, las fotografías no son intervenidas por la autora para dar forma propia a un legado familiar, porque ese legado resulta escaso y ha sido mutilado. Pero las fotos están allí, casi al comienzo, y si bien no hay fotomontaje, sí hay un diseño que imita al álbum familiar que debiera iniciarse con esas tomas y permite imaginar una escena original cercana a la "normalidad". Lo que resta por hacer es reponer ese fantasma que es el rostro incompleto del padre "clandestino" en la imagen, pero que es también la memoria "reconstruida" de su madre, quien sigue aún desaparecida y cuya figura se vuelve diminuta frente a la abundancia de datos que permiten elaborar la biografía de Paco Urondo. ${ }^{20}$ 
"Porque era eso lo que yo quería, ver. ¿Ver qué? A los desaparecidos, qué más, qué magia mayor que esa." (Dillon 29)

Aparecida de Marta Dillon es el último "relato autobiográfico" de esta serie y el más reciente. En él, la autora reconstruye la historia de su madre, secuestrada y desaparecida en 1977, cuando ella tenía once años. El desencadenante de la escritura es la aparición de los restos óseos y su identificación por parte del Equipo Argentino de Antropología Forense (EAAF) en el año 2006. El relato avanza por dos vías: por un lado, la narración detallada de las alternativas que llevaron al proceso de identificación de los restos de Marta Angélica Taboada y por otro, el relato de la historia familiar, la reconstrucción de la vida de la madre, de sus amores, de su militancia, de su secuestro y posterior asesinato. Asimismo, se intercala el relato autobiográfico de la autora, sus recuerdos de infancia y de adolescencia, su militancia en organismos de Derechos Humanos, feministas y LGTTTBI, su enfermedad (es portadora del VIH), su casamiento con la cineasta Albertina Carri, directora de un documental emblemático para la generación de los hijos de la militancia, Los rubios (2005). ${ }^{21}$ Todos estos aspectos dan como resultado un texto multifacético en el que se mezcla la "auto/biografía" con la crónica periodística y la poesía. El relato está compuesto por doce capítulos entre los cuales se intercalan once textos breves de naturaleza diversa: poesías, sueños, recuerdos infantiles, transcripción de un documento policial de 1977, en el que se deja asentado en apenas diez renglones, el supuesto enfrentamiento de la policía con un grupo de seis militantes montoneros en el que murió la madre de Dillon.

También en este caso, el secreto familiar se instala desde el momento en que la madre es secuestrada. El padre oculta a sus cuatro hijos lo que en verdad ha ocurrido y recién a los 18 años, en 1984, Dillon reconoce el nombre de su madre en el Diario del Juicio que a principios de los 80 transcribía los testimonios de las víctimas en el juicio a los comandantes de la dictadura. Desde ese momento se inicia "la reconstrucción de la zona desaparecida" (19), que va de 1984 a 2006, y que tiene sus avances y retrocesos como un juego de la oca, que se narra en detalle, y que culmina con la gran ceremonia de entierro de los restos de la madre, con cuya crónica se cierra el relato. Una vez recuperado el cuerpo, la pregunta que se vuelve perentoria es lograr desentrañar si la madre era consciente del peligro que la acechaba - "Alguna vez pensé que ella ignoraba el olor de la 
matanza alrededor, que por alguna razón se sentiría a salvo, que no sabía exactamente lo que le podía pasar" (175; énfasis en el original) - no porque pusiera en peligro a sus hijos, sino porque, al contrario, la hija, a sus diez u once años, no percibió en ningún momento una situación de riesgo. La imagen de esa mujer ausente se recupera como madre y mujer y se exalta la energía y la capacidad para militar, amar y ocuparse de sus hijos y el "deseo", entendido en términos deleuzianos, ${ }^{22}$ como aquello que movía sus actos: "Ahora creo que puedo sentir su cansancio, la cantidad de energía que debería desplegar para mantener amarrado todo lo que quería, para atravesar cada día sin dejar que se filtrara el miedo. Porque si ella lo sintió, yo apenas me di cuenta" (176). ${ }^{23}$ No es una figura de mártir la que se intenta reponer: "Yo no creo que ella haya dado la vida" (176), dice la hija, negando de este modo un acto de arrojo suicida. Negar el instinto suicida de la madre al no ser más precavida en los meses anteriores a su secuestro no implica falta de compromiso de su parte sino, por el contrario, permite acentuar el peso en una forma de persecución insólita, un arrebato brutal, cargado de máxima violencia que se traduce en el asesinato reconstruido en distintas partes del relato. No hay reproche por algún tipo de abandono ni evaluación crítica del papel jugado por la "Orga" en lo ocurrido. La perspectiva desde la que se trae al presente la figura materna es esencialmente la del espacio doméstico, espacio que requiere una organización que muchas veces se invisibiliza. No es tanto la militante aguerrida que vuelve como la mujer que busca sus hijos a la salida de la escuela y juega con ellos sobre la cama planteando "cómo ser madre cuando se palpita la posibilidad del abandono" (181).

No hay fotografías en el cuerpo del texto, pero sí en la tapa: una figura femenina de cuerpo entero y de espaldas en bikini sobre la playa; y en la contratapa, esa misma figura, en el mismo escenario, gira la cabeza y mira a la cámara, mientras se aleja caminando sobre la arena. La foto podría ser una vieja diapositiva de las que se tomaban en los años 6o, y exhibe sobre su superficie todo el desgaste que ese soporte visual puede sufrir al cabo de los años: rayas, punteados, manchas. La referencia indica "archivo familiar". Luego sabremos que esa es la madre "aparecida" y que la foto está tomada en alguna playa del Uruguay.

Luego de un epígrafe de Hélène Cixous, ${ }^{24}$ lo primero que leemos es uno de esos breves capítulos y allí se alude a una fotografía en la que están madre e hija:

Frente a mí hay una foto de mi mamá conmigo. Estamos tendidas sobre la arena, apenas se ve la espuma del mar en un ángulo. Ella tiene la cara tapada por el pelo, a mí sólo se me ve la nuca y su mano enredada en mis rulos. No sé cuántos años 
puedo tener en la foto, puedo decir que su codo se apoya justo en el nacimiento de mi espalda y sus dedos se pierden en mi pelo. ¿Qué edad hay que tener para que el antebrazo de tu madre tenga la exacta medida de tu torso? (11)

Este es el umbral, la fotografía abre el relato; luego comienza, en otro capítulo, la narración de la historia propiamente dicha. Como dijimos, no hay fotografías en el interior del texto, que se encuentra rodeado por las fotos de tapa y contratapa, pero sí la descripción de una foto que se torna emblemática y disparadora de todo el relato. Como en los otros textos, se recupera, se reconstruye el álbum familiar como soporte de una historia que ha sido ocultada y de la que se hacen cargo las hijas. Podemos pensar que esa foto, tomada en la playa, forma parte de la misma serie de aquellas que ilustran el libro en su exterior. Pero en lugar de convocar a una reflexión nostálgica y emotiva de ese momento de contacto físico entre madre e hija niña, la imagen dispara una pregunta de tipo antropométrico, en la que el enigma de la edad será "calculada" por la comparación entre longitudes de huesos, antebrazo de madre y torso de niña. Allí, en un texto breve, que no ocupa más de ocho renglones, aparecen las dos coordenadas por la cuales va a transitar la "auto/biografía" de Dillon: por un lado, la reconstrucción de la imagen materna, de su historia en la que se anuda la familia y la militancia, y del vínculo entre madre e hija; por el otro, la minuciosa crónica del trabajo de identificación científica llevado a cabo por el Equipo Argentino de Antropología Forense (EAAF), en el que se clasifican, se miden, se analizan genéticamente los restos humanos encontrados por los organismos de Derechos Humanos.

En el segundo de estos mini capítulos, unas páginas más adelante, pasamos de la foto, a la evocación "naturalista" de los huesos que han sido identificados:

¿La encontraron? ¿Qué habían encontrado de ella? ¿Para qué quería yo sus huesos? ... Esquirlas de una vida. Destello marfil que desnudan las aves de carroña a campo abierto. Ahí donde se llega cuando se va a fondo, hasta el hueso. Lo que queda cuando todo lo que en el cuerpo sigue acompañando al tiempo se ha detenido, la hinchazón de los gases, el goteo de los fluidos, el banquete de la fauna cadavérica, el ir y venir de los últimos insectos. Después los huesos. (33)

En ese transcurrir se juega el paso de la vida a la muerte y se hace el duelo de un cuerpo perdido. Ese duelo que debió iniciarse con el dato empírico e irrefutable de un cuerpo muerto, pero "íntegro" como si estuviera vivo, debe anclarse en aquello que tenemos vedado observar, la abyección de los cuerpos que se descomponen, y que solamente imaginamos o nos invade 
involuntariamente como una película de terror. Dillon ve lo que la cultura nos prohíbe ver: los restos de nuestros muertos. La abyección, ${ }^{25}$ aquello que se instala en el plano de la fantasía, la desintegración del cuerpo, ${ }^{26}$ es reconstruida para llegar a lo que se ha recuperado: una calavera y unos pocos huesos que están allí para que la "desaparecida" ahora se transforme en "aparecida" ${ }^{27}$ Ante los restos óseos, el reconocimiento se encuentra mediado por una abstracción numérica que la medicina forense y sus modernas técnicas de filiación genética por ADN traducen en un porcentaje y que los deudos deben aceptar como una prenda de fe: "En el vaivén de la búsqueda, Antropólogos siempre fue un destino. Buscado porque al menos allí generan la ilusión de que algo se puede hacer. Porque lo que ellos rescatan de la sombra es algo concreto" (25).

En uno de los capítulos finales, la protagonista recibe un rollo de película con filmaciones familiares en súper 8 ensambladas por su hermano, e insiste en verlas cuatro veces; en cada una de ellas hay una descripción: más detallada la primera, más sintéticas las otras tres. Lo que se busca allí es recuperar el rostro, la mirada de la madre; pero ese empeño resulta frustrante, pues la cámara sigue a los niños que eran en ese momento Marta y sus tres hermanos, y el cuerpo materno se limita a imágenes fragmentarias y fugaces en las que aparecen unos dedos con las uñas pintadas apretando un cigarrillo, una piernas, retazos de un traje de baño, una mano que dice adiós, y cuando los cuerpos de padre y madre están enteros en una de las tomas, la cámara está demasiado lejos como para reponer los rostros. Este empeño que se textualiza en cuatro oportunidades responde a un anhelo por recuperar una imagen más "real" de esa madre viva. Pero lo único que queda es inventar y la desilusión "porque no vi su cara, no me miraba, porque no veía lo que quería ver..." (173). En esta filmación los adultos son personajes secundarios, son los padres quienes filman a sus hijos para atesorar una memoria "animada" de la infancia. Sin embargo, esta lógica es desafiada y se revela inútil cuando son los hijos quienes buscan recuperar, en esas películas caseras, imágenes más "reales" de los padres desaparecidos.

Este capítulo se cierra con la descripción de varias fotos. Una de ellas es del último tiempo antes del secuestro, cinco años después de la filmación en súper 8: la madre mira a su hijo Juan, y el detalle particular es que entre los dos "hay un vaso de plástico en el aire, nítido, flotando, el parpadeo del obturador como un mago clavando un dardo en el devenir del tiempo" (180). Dillon lee esa fotografía y advierte que ese objeto volador que desafía las leyes de gravedad en su vuelo detenido por la cámara es una especie de advertencia de lo que vendría poco tiempo después, del derrumbe y la ausencia final. 
Las imágenes fotográficas, reproducidas en el paratexto o descriptas en su interior, envuelven el texto de Dillon, ofician de umbral y de cierre en lo que sería un trabajo de exhumación de las memorias de la hija antes de la ceremonia del entierro de los restos encontrados de su madre. El álbum familiar queda presidido por una foto que intenta recuperar la imagen de una madre viva pero que, al mismo tiempo, anticipa un uso científico y forense de los "huesos" para su identificación, proceso que la narración viene a describir en detalle. Reconocer esos "restos" como propios es la base sobre la cual transitar un duelo postergado durante tres décadas.

\section{DE FOTOS Y LEGADOS}

Estas son solo tres obras que habitan un espacio discursivo densamente poblado, en un espectro que va de los registros autoficcionales a las narraciones de las vidas "reales" y en el que los artistas de esta generación de hijos e hijas van construyendo sus propias historias, a partir de modos de apropiación singulares de ese pasado que viene modelado por el cúmulo de historias de quienes sobrevivieron al terrorismo de Estado. ${ }^{28}$ Sin embargo, aquí se amplía la lista de víctimas y sobrevivientes: los bebés y los niños también fueron protagonistas en esta historia y vienen ahora a ofrecer sus propias versiones. ${ }^{29} \mathrm{El}$ álbum familiar les concede una matriz sobre la cual desarrollar sus relatos dentro del "espacio biográfico". Allí, en esas imágenes, se vuelven visibles los cuerpos y los rostros que han sido arrebatados y, por esa razón, no pueden ser ignorados por ninguna de estas obras en las que se escribe tardíamente una novela familiar. Desde allí, desde esa otra orilla, las fotos siguen enunciando un reclamo no acallado, señalado por Arfuch, interpelando a sus descendientes. Como afirma Joël Candau:

Los herederos de una memoria del horror se esfuerzan por recoger los fragmentos de sus historias familiares y por reconstruir así una memoria que les permita, tal vez, librarse de un sentimiento frecuente de culpabilidad: de ser culpables "de no estar a la altura de los seres desaparecidos e idealizados", culpables de no ser felices, culpables de olvidar a veces la tragedia ... Trágica o ignominiosa, la ascendencia golpea así, de manera diferenciada pero siempre muy poderosa, la memoria genealógica de un individuo o de un grupo y, por lo tanto, su identidad. $(151)$

Leer los usos que cada texto hace de los registros fotográficos puede ser una manera de comprender proyectos de escritura singulares que, sobre el fondo común de la violencia y la desaparición, y de la militancia en los organismos que agrupan a los hijo/as, apuntan a recomponer una memo- 
ria que transita entre lo privado y lo público, entre los lazos rotos de la afectividad doméstica y familiar, y aquellos otros que se tienden en las luchas colectivas por la memoria.

Universidad Nacional de La Pampa

Universidad Nacional de San Martín

\section{NOTAS}

1 La autora toma esta idea de un artículo de W.J.T. Mitchell aparecido ese mismo año y que lleva como título “¿What Do Pictures Really Want?” (“Álbum” 11).

2 “Acaso el álbum no es el cronotopo más rotundo y reconocible de nuestra identidad?", se pregunta Arfuch (“Álbum” 8). Si bien la idea de álbum remite a una estructura necesariamente discontinua y fragmentaria, con fotos mezcladas e incluso desconocidas, que han perdido su anclaje temporal preciso, su existencia supone, no obstante, la narrativa de una historia familiar en la que se inserta la propia fábula personal de cada uno de sus integrantes.

3 Celina Van Dembroucke (2013) realiza un análisis detallado de estos recordatorios a partir de dos hipótesis que guían su lectura: "La fotografía carnet publicada en el recordatorio actúa a modo de tumba provisoria de un duelo que es, a su vez, infinito; ... estas fotografías no están confinadas a la representación de quienes retratan, sino que han adquirido un peso simbólico por el cual un solo rostro tiene el poder de representar a todas las víctimas que se cobró la represión estatal de la década del 70 en la Argentina” (120).

4 Es importante pensar a estas hijas como víctimas ellas mismas de ese terrorismo para no mitigar la tragedia y el trauma que estas situaciones provocaron. En el caso de Ángela Urondo Raboy, una de las autoras cuya obra voy a analizar, su testimonio demuestra con claridad que, siendo un bebé de pocos meses, fue secuestrada y estuvo en cautiverio durante varios días. En los otros casos, también se podría hablar de "víctimas" por las consecuencias que tuvieron en sus vidas familiares la desaparición de sus padres. Si hablo de "hijas" es para señalar tanto la diferencia generacional como aquella de género, que van a incidir en la forma de escribir el trauma.

5 Un breve listado incluiría: La casa de los conejos (2008) de Laura Alcoba; 76 (2007) y Los topos (2008) de Félix Bruzzone; Soy un bravo piloto de la nueva China (2011) de Ernesto Semán; Una muchacha muy bella (2013) de Julián López; Diario de una princesa Montonera (2012) de Mariana Eva Pérez; ¿Quién te creés que sos? (2012) de Ángela Urondo Raboy; y Aparecida (2015) de Marta Dillon. A este corpus "literario", habría que agregar un número importante de películas, documentales, performances, obras de teatro, etc. Algunas de ellas, 
como La casa de los conejos y la obra de teatro Mi vida después de Lola Arias, son abordadas en Maristany.

6 Hay dos factores para pensar en la emergencia de esta serie de "relatos auto/biográficos". Por un lado, la derogación de las Leyes de Impunidad en el Congreso de la Nación en el año 2003 permitió la reapertura de las causas que investigaron el terrorismo de Estado en el marco del delito de genocidio y la posterior Declaración Judicial de Nulidad en el año 2005 que declaró la inconstitucionalidad de la leyes de Punto Final y Obediencia Debida. Este marco legal e institucional, es lo que permite llegar a la verdad sobre la propia identidad (Urondo Raboy), la de familiares como hermanos apropiados (Pérez) y sobre el destino de las víctimas (Dillon), puntos de arranque de las tres narrativas aquí analizadas. Esa dinámica judicial, con sus testimonios y audiencias públicas, forma parte de las narraciones autobiográficas de cada una de las hijas. Por otro lado, también sería importante un dato empírico como la llegada a la edad adulta de las autoras, que pueden comenzar a recordar y a evaluar sus propias experiencias militantes en los movimientos de derechos humanos y, en especial, en la agrupación H.I.J.O.S. que dio voz a los reclamos de esta nueva generación de jóvenes y que impuso como uno de los métodos de la sociedad civil para luchar contra el olvido y la impunidad de aquellos años, el "escrache" por medio del cual se identificaba y señalaba a quienes habían participado del terrorismo estatal.

7 Los testimonios analizados por Nofal son: Recuerdos de la muerte (1984) de Miguel Bonasso; The Little School, Tales of Disappearance \& Survival (1985) de Alicia Partnoy; Poder y desaparición. Los campos de concentración en Argentina (2001) de Pilar Calveiro; El tren de la victoria. Una saga familiar (2003) de Cristina Zuker; Montoneros. La buena historia (2005) de José Amorim; Monte Chingolo. La mayor batalla de la guerrilla argentina (2003) de Gustavo PlisSterenberg; y Fuimos soldados. Historia secreta de la contraofensiva montonera (2006) de Marcelo Larraquy.

8 Tal vez, del corpus reunido por Nofal sea el texto de Cristina Zuker, El tren de la victoria (2003), uno de los que preludia y se acerca al formato de los textos "auto/biográficos" que estamos abordando; el relato familiar en este caso, ya no se arma desde el lugar de "hija" sino como "hermana" de un militante secuestrado y asesinado en 1980: "El lector recorre las páginas de un álbum de fotografías; las personas que se representan son parientes y amigos jugando un rol particular en la vida de los protagonistas" (Nofal 252).

9 Me refiero al corpus mencionado en nota 5. Casi todas las obras allí incluidas contienen la fotografía como tópico o como procedimiento formal para hablar de los desaparecidos.

10 En su estudio ya clásico, LaCapra distingue entre escribir el trauma y escribir acerca del trauma y recupera para la primera modalidad discursividades que 
se alejan del modelo historiográfico clásico para pasar a registros ficcionales y testimoniales, en los que sería posible, desde una perspectiva que maneja procedimientos "literarios" como el discurso indirecto libre, presentar la complejidad de la experiencia traumática. Para este autor "el trauma excede a cualquier género o disciplina" e "implica un exceso que abruma al yo y desorienta a la sociedad” (208) por cuanto provoca una perturbación en el orden simbólico, una falta en el proceso ritual o una muerte atroz e injustificable que, en cierto modo, excede los mecanismos de duelo existentes. El manuscrito original del diario anónimo fue probablemente escrito entre 1796 y 1800 y cuenta la licenciosa vida de la princesa Vávara Sofía, hija del príncipe Demetri, gobernador militar, y amante favorita del emperador Pablo I.

12 En una entrevista, Pérez cuenta que inició el blog en diciembre de 2009 y estuvo activo hasta 2011: "Cuando intentaba escribir en la compu, en soledad, no funcionaba. Había algo como muy solemne que no fluía, no terminaba de encontrar la forma. Vamos a probar con un blog, dije, y que salga lo que sea de cada día que tenga que ver con este temita. Empecé a escribir y después reuní lo que tenía para ver si ese material daba para un libro o no" (Rosso). Arfuch, al analizar el impacto de las nuevas tecnologías en el "espacio biográfico", relaciona los diarios íntimos con los weblogs en Internet, "que los ponen al alcance de todos, como uno de los rasgos de la nueva "intimidad pública" (Espacio 256-257).

13 Solamente aparecen las iniciales P y M como firma de algunos correos electrónicos que podrían referir tanto a su denominación de fantasía ("Princesa Montonera") como a las iniciales de su apellido y de su primer nombre. Tampoco aparecen los apellidos de sus padres, simplemente sus sobrenombres: Paty y Jose o las iniciales de los apellidos Jose $\mathrm{M}^{*} \mathrm{P}^{*} \mathrm{R}^{*}$ para el padre; Patricia J*R* para la madre (51). Estos borramientos, junto con la declaración de un registro ficcional en varios momentos, vendrían a cuestionar el estatuto de veridicción de esta "auto/biografía".

14 Al igual que en la "auto/biografía" de Urondo Raboy, como veremos después, hay un reproche hacia la estructura de Montoneros y a los responsables por dejar indefensos a los militantes y "mandarlos al muere".

15 Jordana Blejmar se refiere al uso frecuente del collage fotográfico en las obras visuales de los jóvenes artistas de la nueva generación que intentan crear imágenes de la memoria dictatorial y analiza obras de Lucila Quieto, integrante de H.I.J.OS., en las que la artista interviene imágenes tanto de su padre y su tío desaparecidos, como de íconos de la lucha revolucionaria en Argentina con una fuerte carga simbólica. Blejmar define esta utilización del collage como forma de construir memorias visuales "descontracturadas" y, a través de una memoria lúdica y una mirada "infantil", "minimizar, 
momentáneamente, el contenido dramático de esas imágenes y lugares" (190). Con esta técnica sería posible asimismo crear algo nuevo con los vestigios del pasado: "El collage separa, distancia, repele, pero también une: imágenes, tiempos, texturas" (178).

16 Muchas de estas crónicas aparecieron inicialmente en dos blogs de la autora: Infancia y dictadura y Pedacitos.

17 Roland Spiller señala algunos rasgos comunes de las narrativas postraumáticas que se escribieron en Argentina en las últimas tres décadas que incluyen "elipsis, fragmentaciones, repeticiones, residuos, rupturas y fenómenos de desorganización también en el nivel de la narración. La escritura transforma estéticamente la representación verbal primaria, conectándola con los restos escondidos en el inconsciente" (130). Estos rasgos aparecen en las tres "auto/biografías" que estoy analizando.

18 No tiene firma, por esa razón no se puede utilizar como testamento.

19 Es interesante pensar que aquí es la propia familia la que se encarga de cambiar la identidad o borrar una parte de esa identidad de los niños. Ángela se reencuentra con su tía Beatriz, hermana de Francisco Urondo, y con su medio hermano, cuando ya es adulta y descubre la verdadera historia.

20 Es por esta razón que la escritura de Ángela se empeña por conocer la historia de su madre e intenta reconstruirla en un apartado en el que incorpora testimonios de quienes la conocieron: “Quién es mi mamá? Es una pregunta que me hago casi a diario" (144). Así comienza esa biografía, elaborada sobre la matriz clásica del género y con el aporte documental de quienes la conocieron, de la figura materna que ocupa quince páginas y se remonta a los orígenes inmigratorios y judíos de los abuelos maternos.

21 Sobre este documental y la polémica que originó ver Maristany, "Rememoración e irreverencia. Los hijos de la dictadura cuentan su historia".

22 Deleuze y Guattari en El Anti Edipo, en una perspectiva anticapitalista y antipsicoanalítica, destacan el vínculo indiscernible entre el ejercicio de un deseo actuante como voluntad o ganas de vivir, de crear, de amar, y una práctica revolucionaria, anticipatoria de una nueva sociedad: "Nosotros decimos que el campo social está inmediatamente recorrido por el deseo, que es un producto históricamente determinado, y que la libido no necesita ninguna mediación ni sublimación, ninguna operación psíquica, ninguna transformación, para cargar las fuerzas productivas y las relaciones de producción. Sólo hay deseo y lo social y nada más" (34-36). Este lugar central otorgado al deseo permite desbloquear la rígida frontera generizada entre lo público y lo privado que fuera denunciado por el feminismo de los años 60 al manifestar que "lo personal también es político" y pareciera estar actuando en las imágenes de las mujeres/madres que estos relatos procuran construir. 
23 Un aspecto para destacar en los tres textos es la recuperación de las madres en tanto figuras de mujer que desafiaron la rígida moral sexual existente tanto en la sociedad como en las organizaciones políticas a las cuales pertenecían.

Aparece así una militancia entendida en otros términos que no es solamente la lucha armada sino también la búsqueda de una liberación de los cánones patriarcales y conservadores que marcaban la vida cotidiana de las mujeres, aspecto usualmente invisibilizado en los testimonios de los sobrevivientes.

24 "Quiero ver con mis ojos la desaparición. Lo intolerable es que la muerte no tenga lugar, que me sea sustraída. Que no pueda vivirla, tomarla en mis brazos, gozar sobre su boca del último suspiro" (9).

25 Sigo aquí la idea de abyección que desarrolla Kristeva: "El cadáver - visto sin Dios y fuera de la ciencia - es el colmo de la abyección. Es la muerte infestando la vida" (35).

26 Solamente asequible en las pesadillas, en los relatos de terror o en la fantasía médica del naturalismo decimonónico como en el cuento de Eduardo Wilde "La primera noche de cementerio" en la que el narrador describe con la fría mirada del científico, el proceso de descomposición de un cadáver: "El cuerpo de una joven yace allí en plena fermentación ... Más abajo hay dos hoyos llenos de una gelatina negruzca que desborda por los ángulos: son los ojos ... El vientre del cadáver es una pulpa informe, movediza, en que entran y salen legiones vivientes, ocupadas al parecer en una negociación muy urgente. Las ropas han caído entre los muslos formando canaletas por las que corre un líquido ocre y espeso" (129-130).

27 La reflexión sobre el cuerpo materno y su desintegración da pie al relato de su propio cuerpo afectado por el VIH, y de este modo la biografía de la madre, erigida sobre incertidumbres e interrogantes que se intentan responder, se torna autobiografía. En este sentido, es importante pensar en el modelo de familia "alternativa" que propone el relato de Dillon en el presente de la enunciación y todo lo que va recogiendo la narración como un testimonio de la fuerte militancia de la autora en el ámbito del feminismo y de los derechos de las minorías sexuales. Este sería el modo en que Dillon se hacer cargo y continúa el legado de militancia de la madre.

28 Me refiero a la categoría "autoficción” definida por Régine Robin como "una ficción que alguien decide hacer de sí mismo", pero que "no hace de él un autobiógrafo, (alguien que cuenta su vida para encontrarle un sentido o una justificación), sino un 'autoficcionario', un artista que extrae de sí emociones, sensaciones, imágenes de lugares y gentes y los pone en palabras" (Arfuch, "Álbum" 8).

29 En el blog de Ángela Urondo se puede visitar la serie denominada "Infancia y dictadura” en la que se reúnen más de treinta historias de niños que fueron víctimas de la violencia terrorista del Estado. La serie incluye un breve relato 
del momento traumático de la irrupción de las fuerzas armadas que presenciaron los niños y una fotografía familiar solos o con sus padres y hermanos.

OBRAS CITADAS

alC о в A, LAURA. La casa de los conejos. Buenos Aires: Edhasa, 2008.

A M AD O, A A. "Ficciones críticas de la memoria". Pensamiento de los confines 13

(2003): 55-63.

AM ORIM, Jos É. Montoneros: La buena historia. Buenos Aires: Catálogos, 2005.

AR F UCH, LEONOR. "Album de familia". Punto de Vista 56 (1996): 6-11.

-. "Cronotopías de la intimidad". Pensar este tiempo. Espacios, afectos, pertenencias.

Comp. Leonor Arfuch. Buenos Aires: Paidós, 2005. 237-290.

-. El espacio biográfico. Dilemas de la subjetividad contemporánea. Buenos Aires:

Fondo de Cultura Económica, 2007.

BLEJMAR, JORDANA. "La Argentina en pedazos. Los collages fotográficos de Lucila

Quieto". Instantáneas de la memoria. Fotografía y dictadura en Argentina y

América Latina. Eds. Jordana Blejmar, Natalia Fortuny y Luis Ignacio García.

Buenos Aires: Libraria Ediciones, 2013. 173-193.

в On A S o, m I GUE L. Recuerdo de la muerte. Buenos Aires: Bruguera, 1984.

BRUZZOne, FÉLIX. 76. Buenos Aires: Editorial Tamarisco, 2007.

一. Los topos. Buenos Aires: Mondadori, 2008.

Calveiro, Pilar. Poder y desaparición. Los campos de concentración en Argentina.

Buenos Aires: Colihue, 2001.

CAN DA U, J ö̈ L. Memoria e identidad. Buenos Aires: Del Sol, 2001.

Deleuze, gilles y félix guAttari. El Anti-Edipo. Capitalismo y esquizofrenia.

Trad. Francisco Monge. Barcelona: Paidós, 1998.

Dillo N, MARTA. Aparecida. Buenos Aires: Sudamericana, 2015.

DURÁ N, VA LE R I A. "Imágenes íntimas, heridas públicas". Instantáneas de la

memoria. Fotografía y dictadura en Argentina y América Latina. Eds. Jordana

Blejmar, Natalia Fortuny y Luis Ignacio García. Buenos Aires: Libraria

Ediciones, 2013. 157-172.

KR IS TeVA, Julia. Poderes de la perversión. Madrid: Siglo XXI, 1988.

LACA PRA, D O MIN ICK. Escribir la historia, escribir el trauma. Buenos Aires: Nueva

Visión, 2005.

LAR RA QUY, MARCE Lo. Fuimos soldados. Historia secreta de la contraofensiva

montonera. Buenos Aires: Aguilar, 2006.

Ló Pe Z, JU li Án. Una muchacha muy bella. Buenos Aires: Eterna Cadencia, 2013.

Los rubios. Dir. Albertina Carri. Prod. Marcelo Céspedes, 2003. 
MARISTANY, JoSÉ. "Rememoración e irreverencia: los hijos de la dictadura cuentan su historia". Conflictos y utopías. Debates en la literatura y la crítica argentina. Comp. María Elena Legaz. Córdoba: Ediciones Recovecos, 2012. 185-206.

Mi vida después. Dramaturgia y dirección por Lola Arias.Teatro Sarmiento, Buenos Aires. 18 abril 2009.

NOFAL, ROSSANA. "Partes de guerra en la literatura testimonial argentina". Contratiempos de la memoria en la literatura argentina. Eds. Miguel Dalmaroni y Geraldine Rogers. La Plata: EDULP, 2009. 239-259.

Partn oy, Alicia. La escuelita. Relatos testimoniales. Buenos Aires: La Bohemia, 2006.

Pérez, marian a eva. Diario de una Princesa Montonera-110\% Verdad-. Buenos Aires: Capital Intelectual, 2012.

PLIS-ST ER EN B E RG, GU ST A V o. Monte Chingolo. La mayor batalla de la guerrilla argentina. Buenos Aires: Planeta, 2003.

Rosso, LAur A. "Estar ahí". Entrevista a Mariana Eva Pérez. Las 12. Suplemento semanal de Página 1211 mayo 2012. S. pag. Web.

SEMÁn, ER nesto. Soy un bravo piloto de la nueva china. Buenos Aires: Mondadori, 2011.

SPILLER, ROLAND. "Memorias en movimiento: la transmisión generacional del saber del saber de la vida en la narrativa argentina (1980-2004)". Contratiempos de la memoria en la literatura argentina. La Plata: EDULP, 2009. 121-152.

URONDO RABOY, Án GELA. ¿Quién te creés que sos? Buenos Aires: Capital Intelectual, 2012.

VAN DEMBROUCKE, CELINA. "Retratos. Las fotografías carnet de los desaparecidos en los recordatorios de Página/12". Instantáneas de la memoria. Fotografía y dictadura en Argentina y América Latina. Eds. Jordana Blejmar, Natalia Fortuny y Luis Ignacio García. Buenos Aires: Libraria Ediciones, 2013. 119-132.

vezzetti, héct or. "Políticas de la memoria: el Museo en la ESMA". Punto de Vista 79 (2004): 3-8.

WILDE, E DUARD o. "La primera noche de cementerio". Prometeo \& Cia [1899]. Buenos Aires: Biblioteca Nacional-Ediciones Colihue, 2005. 117-132. ZU KER, CR IST INA. El tren de la victoria. Una saga familiar. Buenos Aires: Sudamericana, 2003. 